\title{
Lipid Bilayer Composition Affects Transmembrane Protein Orientation and Function
}

\author{
Katie D. Hickey and Mary M. Buhr \\ Department of Animal and Poultry Science, University of Guelph, Guelph, ON, Canada N1G 2W1 \\ Correspondence should be addressed to Katie D. Hickey, katiehickey@hotmail.com
}

Received 15 October 2010; Accepted 21 December 2010

Academic Editor: Rhoderick Brown

Copyright ( $) 2011$ K. D. Hickey and M. M. Buhr. This is an open access article distributed under the Creative Commons Attribution License, which permits unrestricted use, distribution, and reproduction in any medium, provided the original work is properly cited.

\begin{abstract}
Sperm membranes change in structure and composition upon ejaculation to undergo capacitation, a molecular transformation which enables spermatozoa to undergo the acrosome reaction and be capable of fertilization. Changes to the membrane environment including lipid composition, specifically lipid microdomains, may be responsible for enabling capacitation. To study the effect of lipid environment on proteins, liposomes were created using lipids extracted from bull sperm membranes, with or without a protein $\left(\mathrm{Na}^{+} \mathrm{K}^{+}\right.$-ATPase or $\alpha$-amylase). Protein incorporation, function, and orientation were determined. Fluorescence resonance energy transfer (FRET) confirmed protein inclusion in the lipid bilayer, and protein function was confirmed using a colourometric assay of phosphate production from ATP cleavage. In the native lipid liposomes, ATPase was oriented with the $\beta$ subunit facing the outer leaflet, while changing the lipid composition to $50 \%$ native lipids and $50 \%$ exogenous lipids significantly altered this orientation of $\mathrm{Na}^{+} \mathrm{K}^{+}$-ATPase within the membranes.
\end{abstract}

\section{Introduction}

Lipid rafts contain lipids, glycosylphosphatidylinositol(GPI-) anchored proteins and various signal transduction proteins $[1,2]$ that engage the microdomain in cell signaling and cell adhesion events [3]. Capacitation is a process whereby spermatozoa gain the ability to fertilize through a series of membrane changes including a reorganization of membrane lipids and proteins [4,5]. Lipid rafts in head membranes of uncapacitated sperm are uniformly distributed but become restricted to the periacrosomal region during capacitation [6], suggesting rafts are associated with capacitation. One particular protein involved in cell signaling during capacitation, $\mathrm{Na}^{+} \mathrm{K}^{+}$-ATPase [7], is extremely sensitive to its lipid environment and its function is uniquely damaged when sperm are cryopreserved [8], a process that also reduces fertility. Loss of $\mathrm{Na}^{+} \mathrm{K}^{+}$-ATPase function postthaw, whether caused by cryopreservationinduced direct damage to the protein and/or alterations in the protein's lipid environment [9], could cause the loss of fertility. $\mathrm{Na}^{+} \mathrm{K}^{+}$-ATPase is a ubiquitous transmembrane protein consisting of alpha $(\alpha)$ and beta $(\beta)$ subunits $[10,11]$, which is well known to function as an ion-transporting enzyme [12], but also has been recently shown to act as a transmembrane signalling molecule in somatic cells [13] and even more recently in sperm [7]. Although $\mathrm{Na}^{+} \mathrm{K}^{+}$-ATPase is not associated with lipid rafts in brain synaptosomes [14], MDCK cells, or enterocytes [15], it is enriched in lipid raft fractions of gastric luminal cells [16], hepatocytes [17], renal epithelial [15], outer medulla kidney, and cardiac cells [18]. Interestingly, $\mathrm{Na}^{+} \mathrm{K}^{+}$-ATPase is stimulated in muscle fibers and fish gill epithelium by a relocation which is mediated by lipid rafts $[19,20]$. The specific effects of lipid environment on $\mathrm{Na}^{+} \mathrm{K}^{+}$-ATPase in sperm membranes is unknown.

Liposomes provide a model membrane system to study protein function $[21,22]$, facilitating assessment of integral membrane proteins without interference from other cell components that may obscure results [23]. Many proteoliposome studies attempt to reproduce a typical membrane by mixing a few commercial lipids as a base composition [24-26], but, logically, using extracted endogenous membrane phospholipids would even more closely mimic the native lipid bilayer including lipid rafts. Functional protein reconstitution into vesicles is dependent on method of 
preparation and lipid composition of the vesicles, necessitating determination of degree of incorporation of a protein into the liposomes before detailed protein function can be reliably and repeatedly evaluated. We hypothesized that lipid composition would affect $\mathrm{Na}^{+} \mathrm{K}^{+}$-ATPase insertion into liposomes, and therefore measured incorporation, function and orientation of $\mathrm{Na}^{+} \mathrm{K}^{+}$-ATPase in liposomes made from lipids extracted from the head plasma membrane (HPM) of bull sperm, and then altered the lipid composition of the proteoliposomes to determine the effect of lipid composition on the nature of the incorporation of $\mathrm{Na}^{+} \mathrm{K}^{+}$-ATPase into lipid vesicles.

\section{Materials and Methods}

2.1. Materials. Adenosine 5'-triphosphate (ATP), sodium chloride $(\mathrm{NaCl}), \mathrm{HEPES}$, ouabain octahydrate, $\alpha$-amylase (Type II-A from Bacillus species), bovine serum albumin (BSA), dog kidney $\mathrm{Na}^{+} \mathrm{K}^{+}$-ATPase, osmium tetroxide, imidazole, ammonium molybdate L-Histidine, carbonyl cyanide 3-chlorophenylhydrazone (CCCP), valinomycin, phosphatidylcholine (PC; 16:0, 18:0,18:1, and 18:2), phosphatidylethanolamine (PE), sphingomyelin (Sph; 18:0), and phosphatidylserine (PS; 16:0) were purchased from SigmaAldrich (Mississauga, ON, Canada). N-(dimethylaminonaphthalene-1-sulfonyl)-1,2-dihexadecanoyl-sn-glycero3-phosphoethanolamine, triethylammonium salt (dansyl DHPE) was from Molecular Probes. Thermo Fisher Scientific was the supplier for chloroform, methanol, ascorbic acid, hydrochloric acid $(\mathrm{HCl})$, sodium citrate dihydrate, sodium arsenite, and glacial acetic acid. Phosphatidylcholine $(20: 4)$, Sph (16:0), PS (18:0 and 18:2), and phosphatidylinositol (PI; $18: 1$ ) were purchased from Avanti (Alabaster, AL), and PC (22:6) and PI (16:0) were from Matreya (Pleasant Gap, PA).

2.2. Lipid Preparation. Lipids were extracted from the head plasma membrane (HPM) of whole bull sperm (33 ejaculates from 14 different bulls) using established methods $[8,9]$, pooled, dried, weighed, resolubilized in chloroform methanol $(2: 1, \mathrm{v} / \mathrm{v})$, divided into equal aliquots containing $1.5 \mathrm{mg}$ lipids, and stored at $-70^{\circ} \mathrm{C}$ under nitrogen gas to provide identical lipid compositions for all liposomes.

2.3. Protein Preparation. Dog kidney $\mathrm{Na}^{+} \mathrm{K}^{+}$-ATPase was purified using an ouabain affinity column [27], freeze dried and stored at $-20^{\circ} \mathrm{C}$. Freeze-dried samples were resuspended in HEPES-buffered saline (HBS; $150 \mathrm{mM} \mathrm{NaCl}$; $8 \mathrm{mM}$ HEPES; $\mathrm{pH} 7.2$ ), pooled and re-aliquoted to provide identical working samples. Aliquots were refrozen under $\mathrm{N}_{2}$ at $-70^{\circ} \mathrm{C}$ to preserve protein function. BSA and $\alpha$-amylase were diluted in HBS to the desired concentration and used immediately.

2.4. Liposome and Proteoliposome Preparation. One aliquot of stored lipids was warmed to room temperature and dried (stream of $\mathrm{N}_{2}$ gas to visible dryness then $1 \mathrm{hr}$ vacuum desiccation). Dried lipids were solubilized by incubation in
HBS ( $0.75 \mathrm{mg} \mathrm{lipid} / \mathrm{mL} ; 60^{\circ} \mathrm{C}, 60$ seconds), then vortexing (30 seconds) with scraping and further incubation $\left(60^{\circ} \mathrm{C}, 30\right.$ seconds). Vortexing and incubation were repeated thrice and the resultant lipid suspension was either used for liposome preparation or placed on ice to cool while the protein was prepared.

Protein (purified $\mathrm{Na}^{+} \mathrm{K}^{+}$-ATPase, $\alpha$-amylase, BSA) was diluted in ice-cold HBS (final concentration, 0.075 or $0.15 \mathrm{mg}$ protein $/ \mathrm{mL}$ ), added to the cooled lipid suspension and vortexed (15 seconds). The resultant lipid protein ratio was $20: 1$ or $10: 1(\mathrm{w} / \mathrm{w})$ in $3.0 \mathrm{~mL}(0.5 \mathrm{mg}$ lipid $/ \mathrm{mL}$ and 0.025 or $0.05 \mathrm{mg}$ protein $/ \mathrm{mL}$ ).

Liposomes or proteoliposomes were created using high pressure nitrogen filtration, which was the best of five methods for consistency of producing small, unilamellar liposomes using bull sperm HPM lipids. The lipid or lipid/protein suspension was forced through a $0.1 \mu \mathrm{m}$ Nuclepore Polycarbonate Membrane (Whatman Inc. Clifton, New Jersey, USA) using high-pressure nitrogen gas $(35 \mathrm{~kg} / \mathrm{cm})$. Resulting liposomes or proteoliposomes were maintained under $\mathrm{N}_{2}$ gas until measurements were taken (within 30 minutes).

\subsection{Determination of Proteoliposome Properties}

\subsubsection{Size}

Dynamic Light Scattering (DLS). Proteoliposome size was assessed by DLS with a Malvern Microfluidizer, model M110-S (Malvern Instruments, Herrenberg, Germany), which provided six independent readings that were then converted by an internal algorithm into liposome diameter [28].

Scanning Electron Microscopy (SEM). Proteoliposomes were settled on polished carbon planchettes, fixed ( 2 hours, $0.5 \%$ $(\mathrm{w} / \mathrm{v}) \mathrm{OsO}_{4}$ in $0.05 \mathrm{M}$ veronal acetate and $0.2 \mathrm{M}$ imidazole), rinsed ( $3 \mathrm{x}, 0.2 \mathrm{M}$ imidazole), and then dehydrated in increasing concentrations of ethanol $(50 \%, 70 \%, 90 \%$, then $3 x$ in $100 \%$; [29]). Ethanol was removed by critical point drying with $\mathrm{CO}_{2}$. Planchettes were made conductive by sputter coating with Argon to $15 \mathrm{~nm}$ thick using Emscope K550 sputter coater, (Ashford, Kent, UK) and were viewed using a Hitachi S-570 Scanning Electron Microscope (Tokyo, Japan). Micrographs were captured using Quartz PCI software (Quartz Imaging Corp. Vancouver, Canada).

2.6. Protein Incorporation. Fluorescence resonance energy transfer (FRET) tested incorporation of protein into the bilayer, assessing the fluorescence emission of the FRET probe $\mathrm{N}$-(dimethylaminonaphthalene-1-sulfonyl)-1,2-dihexadecanoyl-sn-glycero-3-phosphoethanolamine, triethylammonium salt (dansyl DHPE) with a spectrofluorometer (Photon Technology International, model A-1010, London, ON, Canada). Excitation scans first established optimal excitation and emission wavelengths for tryptophan and dansyl (excitation ranges 220-315 and 215-400 nm, resp.; emission ranges $350-500 \mathrm{~nm}$ and $425-500 \mathrm{~nm}$, resp.), selecting final conditions of excitation: $278 \mathrm{~nm}$; emission range: $300-520 \mathrm{~nm}$; and scan rate: $1 \mathrm{~nm} / \mathrm{sec}$. 
TABLE 1: Outline of treatments included in the sidedness assay. One batch of proteoliposomes was prepared and split into $6 \times 400 \mu l$ aliquots, each aliquot preincubated ( 2 minutes, room temperature) with reagents indicated, then 0 or $3 \mathrm{mM}$ ouabain added, and samples incubated with ATP $\left(60\right.$ minutes; $\left.37^{\circ} \mathrm{C}\right)$. Adapted from [33].

\begin{tabular}{lcccccccc}
\hline \multirow{2}{*}{ Treatment } & & \multicolumn{3}{c}{ no K $^{+}$} & & $\mathrm{K}^{+}$ & & Opened \\
& & $\mathrm{B}$ & $\mathrm{D}$ & $\mathrm{A}$ & $\mathrm{C}$ & $\mathrm{F}$ & $\mathrm{G}$ \\
\hline \multirow{3}{*}{ Pre incubation } & $\mathrm{K}^{+}$ & 0 & 0 & yes & yes & yes & yes \\
& Ionophores & 0 & 0 & yes & yes & yes & yes \\
& Detergent & 0 & 0 & 0 & 0 & yes & yes \\
\hline Post incubation & Ouabain & 0 & yes & 0 & yes & 0 & yes \\
\hline
\end{tabular}

Liposomes or proteoliposomes for FRET incorporated dansyl DHPE in chloroform/methanol into HPM lipids in darkness to preserve the fluorescence of the dansyl (final concentration: $2 \mathrm{moL} \%$, based on preliminary experiments comparing 1 and $2 \mathrm{moL} \%$ ), and vesicles were formed as before. Emission intensity was assessed with $2.0 \mathrm{~mL}$ liposome/proteoliposome in a quartz cuvette in a 4-place temperature controlled sample chamber filled with $\mathrm{N}_{2}$ gas to minimize any oxidation of protein, which reduces tryptophan fluorescence [30]. Each replicate $(n=3)$ measured fluorescence emission on 4 samples: buffer, liposomes (no protein), ATPase proteoliposomes, and amylase proteoliposomes; all contained $2 \mathrm{moL} \%$ dansyl DHPE. Each sample within each replicate was scanned three times within 20 minutes. One additional replicate substituted BSA as the protein in the proteoliposomes.

2.7. ATPase Function. The function of $\mathrm{Na}^{+} \mathrm{K}^{+}$-ATPase was determined $(n=4)$ as the time-dependent release of inorganic phosphate $\left(\mathrm{PO}_{4}\right)$ from ATP (adapted from $\left.[31,32]\right)$ in the presence of ATPase proteoliposomes, liposomes (no protein), and also $\mathrm{Na}^{+} \mathrm{K}^{+}$-ATPase alone (no liposomes present); all samples were prepared as per liposome/proteoliposome methods. The assay was first optimized in 96-well plates for liposome/proteoliposome testing: sample volume (10, $20,30,40,50,75$, and $100 \mu \mathrm{l} /$ well; $n=3$ ), lipid: protein ratio $(20: 1$ or $10: 1 ; \mathrm{wt}: \mathrm{wt} ; n=4)$, assay incubation times $(20,30,40$, and 60 minutes; $n=4)$ and optimal ATP concentration $(6 \mathrm{mg} / \mathrm{mL}$ or $12 \mathrm{mg} / \mathrm{mL} ; n=1)$. Conditions for the final assay were as follows: proteoliposomes $(50.0 \mu \mathrm{g}$ lipid and $2.25 \mu \mathrm{g}$ protein/well), lipid-only liposomes ( $50.0 \mu \mathrm{g}$ lipid/well), and enzyme-alone $(2.25 \mu \mathrm{g}$ protein/well). The reaction was initiated by the addition of $120 \mu \mathrm{g}$ ATP/well. Each assay contained a standard curve $\left(0-20 \mathrm{nmoL} \mathrm{PO}_{4}\right.$ in duplicate). The assay was incubated $\left(37^{\circ} \mathrm{C}, 60\right.$ minutes). The reaction was stopped by addition of a stop reagent (equal parts of $1 \%(\mathrm{w} / \mathrm{v})$ ammonium molybdate in $12 \%$ SDS (w/v in distilled $\mathrm{H}_{2} \mathrm{O}$ ) and $6 \%(\mathrm{w} / \mathrm{v})$ ascorbic acid in $1 \mathrm{~N} \mathrm{HCl}$ ), incubated (5-8 minutes, room temperature), stabilized ( $2 \%$ sodium citrate $/ 2 \%$ sodium arsenite $/ 2 \%$ acetic acid), and colour allowed to develop (20 minutes, room temperature). Absorbance was then read at $750 \mathrm{~nm}$ using a Powerwave X 340 Microplate Scanning Spectrophotometer (Bio-Tek Instruments Inc., Winooski, Vermont, Canada). A control assay included $\alpha$-amylase and BSA proteoliposomes ( $0.025 \mathrm{mg}$ protein $/ \mathrm{mL} ; n=1$ for each protein).
2.8. ATPase Orientation. The orientation of $\mathrm{Na}^{+} \mathrm{K}^{+}$-ATPase within the proteoliposomes was assessed with an adapted "sidedness" assay [33]. Sidedness expresses whether the protein is located in the proteoliposome bilayer in one of three orientations: inside-out ( $\alpha$ subunit facing outwards), right-side-out ( $\beta$ subunit facing outwards), or not incorporated (not incorporated into the bilayer). Proteoliposomes were made as before, but in a $\mathrm{Na}^{+}$base buffer (130 $\mathrm{mM} \mathrm{Na}^{+}, 4 \mathrm{mM} \mathrm{Mg}^{+2}$ and $30 \mathrm{mM}$ histidine, $\mathrm{pH} 7.0$ ) and identical aliquots were subjected to six treatments $(n=3)$, intact proteoliposomes with no $\mathrm{K}^{+}\left(\right.$no $\left.\mathrm{K}^{+}\right) \pm$ $3 \mathrm{mM}$ ouabain; intact proteoliposomes plus $\mathrm{K}^{+}$ionophores (carbonyl cyanide 3-chlorophenylhydrazone (CCCP) and valinomycin at $1.0 \mathrm{mg} / \mathrm{mL}$ and $0.5 \mathrm{mg} / \mathrm{mL}$ ethanol resp.) so that $\mathrm{K}^{+}$was on the inside and outside of the proteoliposomes $\left(\mathrm{K}^{+}\right) \pm 3 \mathrm{mM}$ ouabain, and liposomes opened with detergent (dodecyloctaethylene glycol monoether $\left(\mathrm{C}_{12} \mathrm{E}_{8}\right), 0.2 \mathrm{mg} / \mathrm{mL}$ ) in the presence of $\mathrm{K}^{+}$(open $\left.\mathrm{K}^{+}\right) \pm 3 \mathrm{mM}$ ouabain. The six resulting treatments (Table 1 ; no $\mathrm{K}^{+}(\mathrm{B})$, no $\mathrm{K}^{+}+$ouabain (D), $\mathrm{K}^{+}(\mathrm{A}), \mathrm{K}^{+}+$ouabain $(\mathrm{C})$, open $\mathrm{K}^{+}(\mathrm{F})$, and open $\mathrm{K}^{+}$ + ouabain $(\mathrm{G})$ ) were then incubated with ATP (60 minutes; $37^{\circ} \mathrm{C}$ ) to measure enzyme activity as before.

Immediately after addition of 0 or $3 \mathrm{mM}$ ouabain, proteoliposomes were provided ATP (final ATP concentration, 3 or $6 \mathrm{mg} / \mathrm{mL}$ ) and assessed for ATPase function, measured as $\mathrm{PO}_{4}$ production (detailed above). Phosphate production was then input into calculations to determine orientation/sidedness as specified by Cornelius [33] based on the treatment groups. Treatment $\mathrm{A}\left(\mathrm{K}^{+}\right)$measures both inside-out and unincorporated $\mathrm{Na}^{+} \mathrm{K}^{+}$-ATPase, while ouabain (treatment $\mathrm{C} ; \mathrm{K}^{+}+$ouabain) inhibits this function. Treatments $\mathrm{B}\left(\right.$ no $\mathrm{K}^{+}$) and $\mathrm{D}$ (no $\mathrm{K}^{+}+$ouabain) are a baseline measure of any background activity. Treatment $\mathrm{F}$ (opened) measures total $\mathrm{Na}^{+} \mathrm{K}^{+}$-ATPase activity in all orientations, while treatment $\mathrm{G}$ (opened + ouabain) inhibits all activity and thus measures basal $\mathrm{Na}^{+} \mathrm{K}^{+}$-ATPase activity. Orientation of $\mathrm{Na}^{+} \mathrm{K}^{+}$-ATPase is thus determined as [33]:

$$
\begin{aligned}
& \text { Inside out: } \frac{(\mathrm{A}-\mathrm{B})}{(\mathrm{F}-\mathrm{G})} \text { OR } \frac{(\mathrm{C}-\mathrm{D})}{(\mathrm{F}-\mathrm{G})} \text {, } \\
& \text { Right side out: } \frac{(\mathrm{F}-\mathrm{A})}{(\mathrm{F}-\mathrm{G})}
\end{aligned}
$$

Not incorporated: $\frac{(B-G)}{(F-G)}$. 
2.9. Effect of Change of Lipid Composition on $\mathrm{Na}^{+} \mathrm{K}^{+}$ATPase Orientation. To determine the impact of lipid composition on $\mathrm{Na}^{+} \mathrm{K}^{+}$-ATPase incorporation and orientation in proteoliposomes, ATPase proteoliposomes were composed of 100\% HPM lipids $\pm 50 \%$ select lipids ([34], HPM : SL $1: 1(\mathrm{w} / \mathrm{w}) ; n=3)$. SL were a complex mix of various phospholipids with known fatty acid composition (PC:PE:SPH : PS : PI ratio $21: 26: 42: 5: 5$ ), with a total saturated:unsaturated fatty acid ratio of approximately $85: 15$ [34].

2.10. Statistical Analysis. All data were analyzed using SAS 9.1 (SAS 9.1 for Windows TS Level 1M3, The SAS Institute Inc., Cary, NC, USA). Equaliy of variances was accounted for in all data sets.

For the function assay $\left(\mathrm{PO}_{4}\right.$ production), general linear model (GLM) evaluated differences in $\mathrm{PO}_{4}$ production among liposomes, proteoliposomes, and $\mathrm{Na}^{+} \mathrm{K}^{+}$-ATPase. Data were checked for normality and square root transformed if necessary to stabilize the variances. Least squares means (LSM) analysis assessed specific differences where type by method interactions were significant, and contrast statements assessed differences among main effects. Differences between these sample types for lipid:protein ratios of 10: and 20:1 were carried out in the same way. $T$ test compared $\mathrm{PO}_{4}$ production by proteoliposomes at a lipid:protein of $10: 1$ or $20: 1$ at 60 minutes of incubation.

A GLM analyzed the FRET raw emission values, determining differences within each replicate using a Tukey's Test. GLM also analyzed the ratios calculated for emission from ATPase proteoliposomes and amylase proteoliposomes expressed relative to the emission intensity of the pure lipid liposomes (set to 100\%) within each replicate. Differences were determined using Tukey's Test.

Calculated amounts of $\mathrm{Na}^{+} \mathrm{K}^{+}$-ATPase in each orientation (inside out, right side out and not incorporated) were analyzed using GLM, and compared by LSM. Overall effect of ouabain was analyzed with GLM, comparing pooled \pm ouabain treatments with LSM of log-transformed data.

\section{Results}

3.1. Proteoliposome Size. Dynamic light scattering showed that the diameters of proteoliposomes created using high pressure nitrogen filtration ranged from $58-72 \mathrm{~nm}$ and were not statistically different than those of the lipid-only liposomes (54-82 nm). The DLS results were verified with SEM micrographs (Figure 1).

3.2. Protein Incorporation. Both $\mathrm{Na}^{+} \mathrm{K}^{+}$-ATPase and $\alpha$ amylase contain endogenous tryptophan [12, 35], which was excited during FRET and emitted light at $345 \mathrm{~nm}$, the wavelength of excitation of the fluorophore dansyl which was tagged on the DHPE. The dansyl absorbed this light and the tryptophan-excited dansyl emitted at the empirically measured $500 \mathrm{~nm}$ (similar to the published maxima of

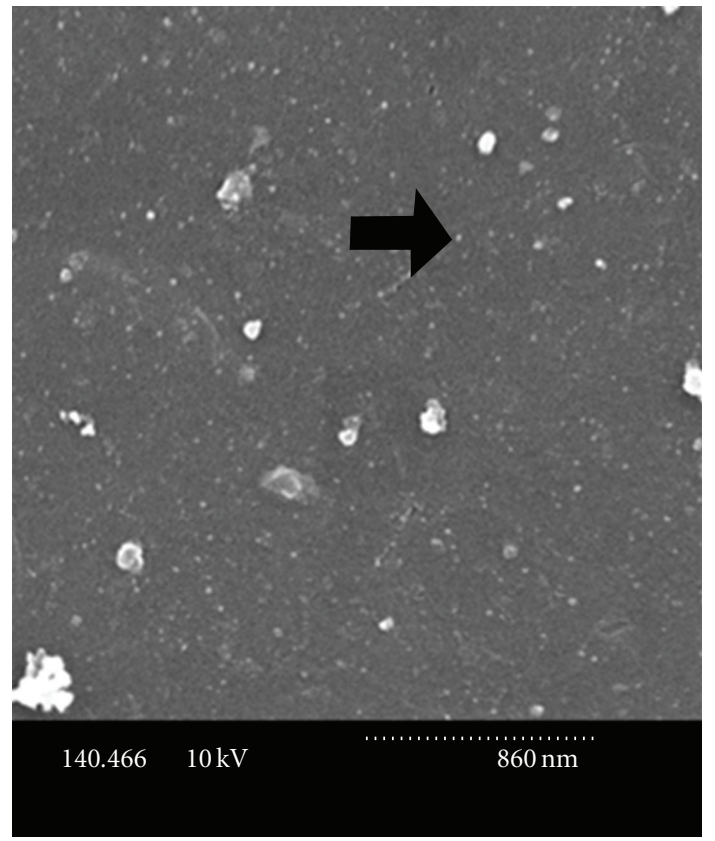

FIgURE 1: SEM micrograph of typical proteoliposomes. These proteoliposomes were made by high pressure nitrogen filtration, fixed on polished carbon planchettes with $\mathrm{OsO}_{4}$, dried, sputter coated with $15 \mathrm{~nm}$ argon, and viewed using a Hitachi S-570 Scanning Electron Microscope. The dotted scale bar across the bottom represents $860 \mathrm{~nm}$. Arrow indicates typical liposome.

$497 \mathrm{~nm}$; [36]). BSA proteoliposomes produced negligible emission, consistent with the fact that BSA is a serum protein and should not incorporate into a membrane. Emission intensity differed overall among different vesicles $(P \leq .001$; Figure 2$)$ and specifically when emission of liposomes with no protein was set to $100 \%(100 \pm 0 \%<$ $114.9 \pm 2.9 \%<161.6 \pm 29.3 \%$ for liposomes, ATPase, and amylase, respectively; $P=.052$ ). It is interesting to note that $\alpha$-amylase proteoliposomes had a greater emission at $345 \mathrm{~nm}$, the wavelength of tryptophan emission, than the ATPase liposomes (Figure 2), in accordance with the greater tryptophan content in the amylase compared to ATPase $[12,35]$.

3.3. Proteoliposome Function. The $\mathrm{Na}^{+} \mathrm{K}^{+}$-ATPase incorporated into HPM lipid vesicles was functionally competent to cleave ATP and release $\mathrm{PO}_{4}$. Proteoliposomes and enzymeonly produced more $\mathrm{PO}_{4}$ with increasing protein concentration in a linear fashion $(P<.001)$, while liposomes did not (Figure 3 ). In data pooled from lipid to protein ratios of $10: 1$ and $20: 1$, proteoliposomes produced more $\mathrm{PO}_{4}$ than liposomes and enzyme-only $(P<.0001)$. Increasing $\mathrm{Na}^{+} \mathrm{K}^{+}$-ATPase content increased $\mathrm{PO}_{4}$ production overall (10:1 lipid: protein $>20: 1 ; P<.0001$ ) and at 60 minutes of incubation (Figure $4 ; P=.046$ ), but individual earlier time points did not differ significantly (data not shown). Therefore, all subsequent assays were conducted with a 10: 1 lipid: protein ratio and a 60 minutes incubation time. Proteoliposomes containing BSA or $\alpha$-amylase were much 


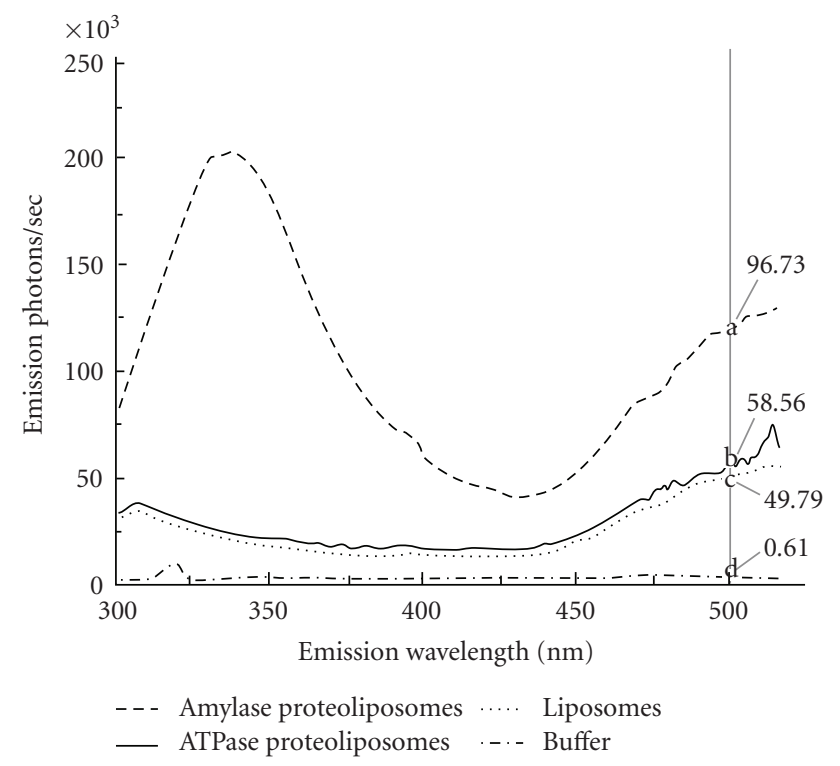

Figure 2: Fluorescence resonance energy transfer to detect ATPase incorporation. Typical fluorescence emission from a single scan of liposomes (dotted) and proteoliposomes containing amylase (dashed) or ATPase (solid) and buffer (dashed dotted). All liposomes were prepared by filtration, contained $2 \mathrm{moL} \%$ dansyl, and were excited at $278 \mathrm{~nm}$, the wavelength of excitation for tryptophan endogenous in the enzymes, and emission recorded over 300 $520 \mathrm{~nm}$; each preparation was scanned 3 times within 20 minutes. Mean emission intensities obtained from the three scans at $500 \mathrm{~nm}$ (grey vertical line), the wavelength of maximum emission of dansyl when excited by emitted light from nearby tryptophan, differed significantly within each replicate (a, b, c, d; $n=3$ ).

less effective at cleaving $\mathrm{PO}_{4}$ than ATPase-proteoliposomes (1.9 and 1.4 versus $7.0 \mathrm{nmoL}$ in a pilot trial).

3.4. ATPase Orientation. Incubation of $\mathrm{Na}^{+} \mathrm{K}^{+}$-ATPaseproteoliposomes with the specific inhibitor ouabain lowered $\mathrm{PO}_{4}$ production $(P \leq .0001)$. The sidedness assay determined that most $\mathrm{Na}^{+} \mathrm{K}^{+}$-ATPase in the proteoliposomes was not incorporated into the bilayer (68.3\%), but all enzymes that were incorporated were facing right side out (31.7\%) and none was inside out (Figure 5).

\subsection{Effect of Change of Lipid Composition on $\mathrm{Na}^{+} \mathrm{K}^{+}$-} ATPase Orientation. The orientation of $\mathrm{Na}^{+} \mathrm{K}^{+}$-ATPase in proteoliposomes made from 100\% HPM lipids (as before) differed from that of proteoliposomes made of a mixture of HPM and SL lipids ( $1: 1 ; \mathrm{wt}$ : wt; HPM : SL proteoliposomes), as assessed by the sidedness assay. Although, as before the $\mathrm{Na}^{+} \mathrm{K}^{+}$-ATPase in both HPM and HPM: SL proteoliposomes was largely not incorporated (84.4\%), inclusion of SL lipids caused all ATPase that was incorporated to be inside out (15.6\%), and none to be right side out, differing significantly from the exclusively right side out ATPase in the pure HPM liposomes $(P=.038$; Figure 6$)$.

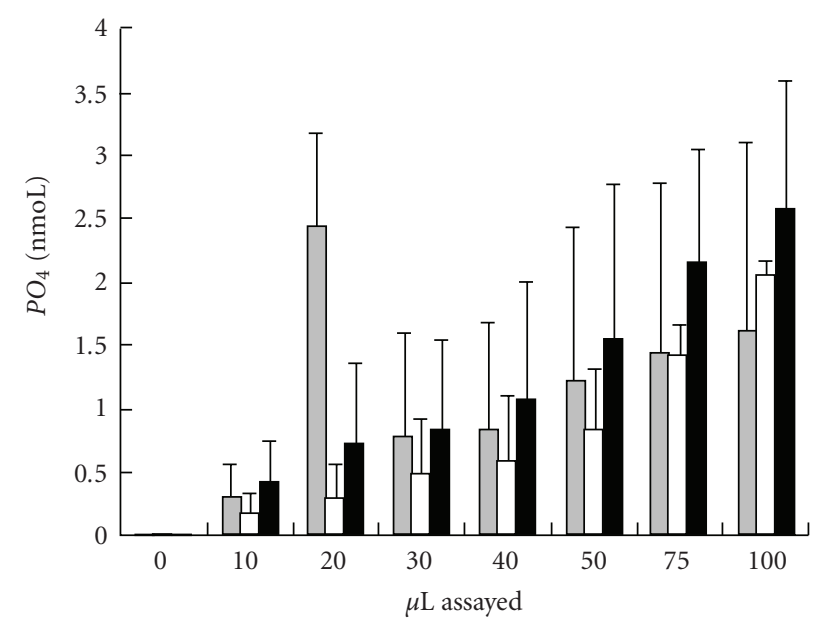

$\square$ Lipid-only liposomes
$\square$ Enzyme only
Proteoliposomes

FIGURE 3: Mean phosphate $\left(\mathrm{PO}_{4}\right)$ detected $(\mathrm{nmoL} \pm \mathrm{SE})$ in liposomes (lipid-only liposomes), $\mathrm{Na}^{+} \mathrm{K}^{+}$-ATPase alone (enzymeonly), and proteoliposomes (liposomes containing ATPase) made by filtration $(n=3)$. Measurements were taken at $0,10,20,30$, $40,50,75$, and $100 \mu \mathrm{l}$. Liposomes and proteoliposomes contained $0.5 \mu \mathrm{g} \mathrm{lipid} / \mu \mathrm{l}$ prior to vesicle production, while proteoliposomes and enzyme-only contained $0.025 \mu \mathrm{g} \mathrm{Na}{ }^{+} \mathrm{K}^{+}$-ATPase/ $\mu \mathrm{l}$. The $\mathrm{PO}_{4}$ in each well was detected by reading colour intensity at $750 \mathrm{~nm}$. The slope across concentrations was linear with increasing concentration for enzyme-only and proteoliposomes $(P<.001)$.

\section{Discussion}

These results convincingly demonstrate that ATPase enzyme can be functionally incorporated into an artificial lipid bilayer and that the lipid composition impacts the orientation and functional ability of amphipathic proteins, consistent with raft theory.

4.1. Proteoliposome Size. The incorporation of $\mathrm{Na}^{+} \mathrm{K}^{+}$ATPase into liposomes did not affect the size of small vesicles made by filtration, when compared to lipid-only liposomes. Small, unilamellar proteoliposomes, such as those produced by high pressure filtration methods established here, are therefore appropriate for the study of protein function [37].

4.2. Protein Incorporation. A measurement of the proximity of lipid and protein molecules in relation to each other using fluorescence resonance energy transfer can be employed to determine if a protein is incorporated into a lipid bilayer. FRET uses the energy from one molecule, the donor, here the tryptophan present in $\mathrm{Na}^{+} \mathrm{K}^{+}$-ATPase or $\alpha$-amylase (see $[12,35]$, resp.), to emit light at a wavelength (tryptophan, $345 \mathrm{~nm}$ ) that excites a second acceptor molecule, here dansyl. Dansyl's resultant emission was then detected at $497 \mathrm{~nm}$ [36]. The key is that the energy transfer can only occur over very short distance, so the donor and acceptor must be in close 


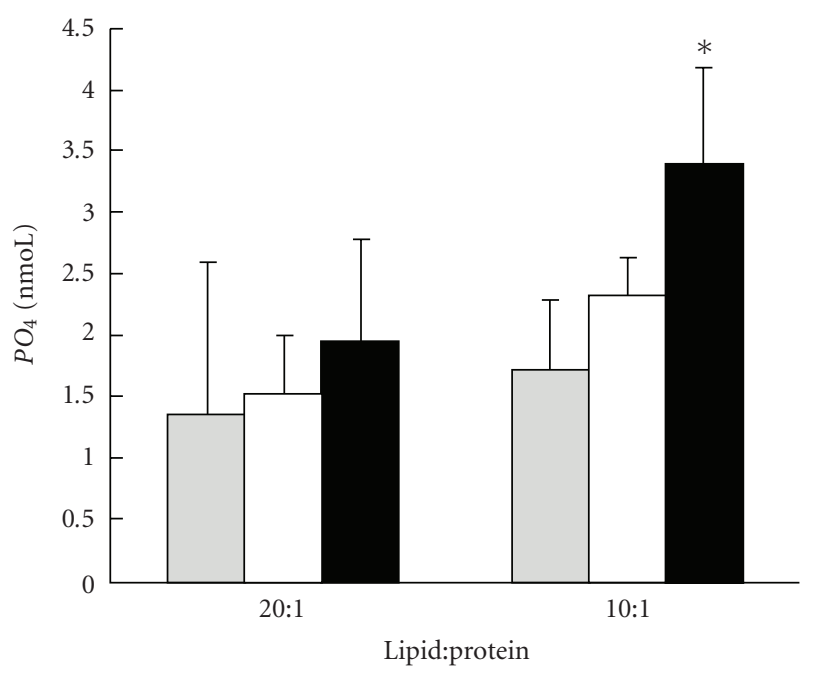

Lipid-only liposomes

$\square$ Enzyme only

Proteoliposomes

Figure 4: Mean phosphate $\left(\mathrm{PO}_{4}\right)$ detected $(\mathrm{nmoL} \pm \mathrm{SD})$ in liposomes (lipid-only liposomes), $\mathrm{Na}^{+} \mathrm{K}^{+}$-ATPase alone (enzymeonly), and proteoliposomes (liposomes containing ATPase) made by filtration with a lipid:protein ratio of 20:1 $(n=4)$ or $10: 1$ $(n=4)$ after 60 minutes of incubation. Liposomes and proteoliposomes contained $0.5 \mu \mathrm{g}$ lipid/ $\mu$ l prior to vesicle production, while proteoliposomes and enzyme-only contained $0.025 \mu \mathrm{g} \mathrm{Na}{ }^{+}$ $\mathrm{K}^{+}$-ATPase $/ \mu \mathrm{l}$ for $20: 1$ and $0.05 \mu \mathrm{g} \mathrm{Na} \mathrm{K}^{+}$-ATPase $/ \mu \mathrm{l}$ for $10: 1 . \mathrm{PO}_{4}$ in each well was detected by reading colour intensity at $750 \mathrm{~nm}$. Significant differences within lipid : protein are marked by $*$.

enough physical proximity to interact in this way. If they are not, emission from the donor molecule will not be absorbed by the acceptor and thereby excite it: the unabsorbed light emitted by the donor will therefore be emitted [36].

Optimal conditions were first established to detect resonance energy transfer, using $2 \mathrm{moL} \%$ dansyl (energy acceptor), a lipid: protein ratio of $10: 1$ (HPM: $\mathrm{Na}^{+} \mathrm{K}^{+}-$ ATPase) which also was the optimum lipid: protein ratio to measure ATPase function. This is similar to the lipid : protein ratios commonly used for $\mathrm{Na}^{+} \mathrm{K}^{+}$-ATPase function studies [38]. Our identified nonoxidizing $\mathrm{N}_{2}$ atmosphere parallels the need because oxidation of tryptophan decreases its fluorescence [30].

Emission from ATPase proteoliposomes was consistently significantly higher than in liposomes alone, indicating that ATPase was incorporated into the lipid bilayer and its tryptophan excited. Amylase proteoliposomes elicited significantly higher dansyl emission than ATPase proteoliposomes because of the approximate 2 -fold greater number of tryptophan moieties in $\alpha$ amylase compared to $\mathrm{Na}^{+} \mathrm{K}^{+}$ATPase $[12,35]$. The $\alpha$-amylase proteoliposomes showed a large peak at the tryptophan emission wavelength, which both corresponds with the reported high level of tryptophan present and suggests that the tryptophan emission exceeded the absorbance capacity of the dansyl molecules in the membrane.

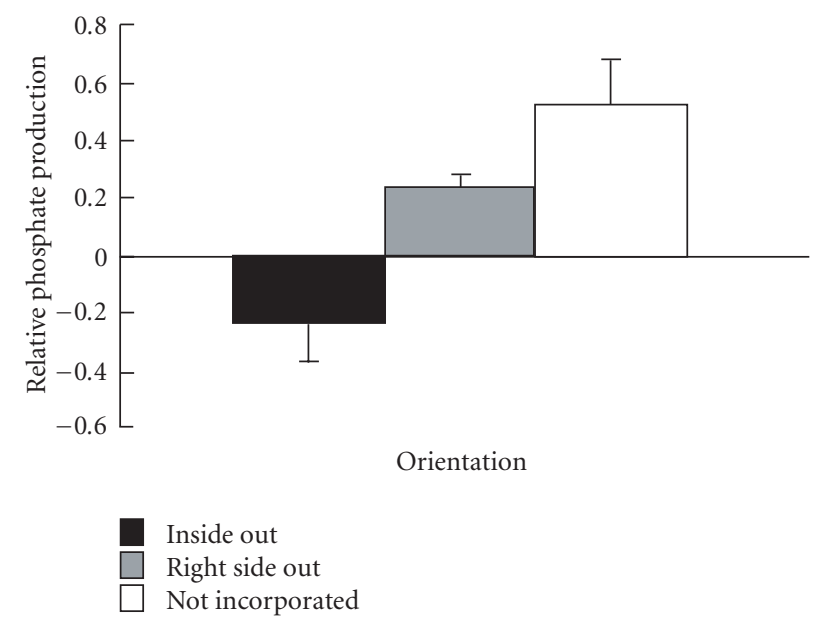

Figure 5: Orientation of $\mathrm{Na}^{+} \mathrm{K}^{+}$-ATPase in proteoliposomes measured by the sidedness assay $(n=3)$. Proteoliposomes were created by nitrogen filtration, incubated \pm ouabain \pm detergent and then function $\left(\mathrm{PO}_{4}\right.$ production from ATP) was measured and used to calculate sidedness [33] to determine the relative amount of $\mathrm{Na}^{+} \mathrm{K}^{+}$-ATPase that was facing inside out, right side out, or was not incorporated. All three orientations of enzyme were statistically different from each other $(P<.05)$.

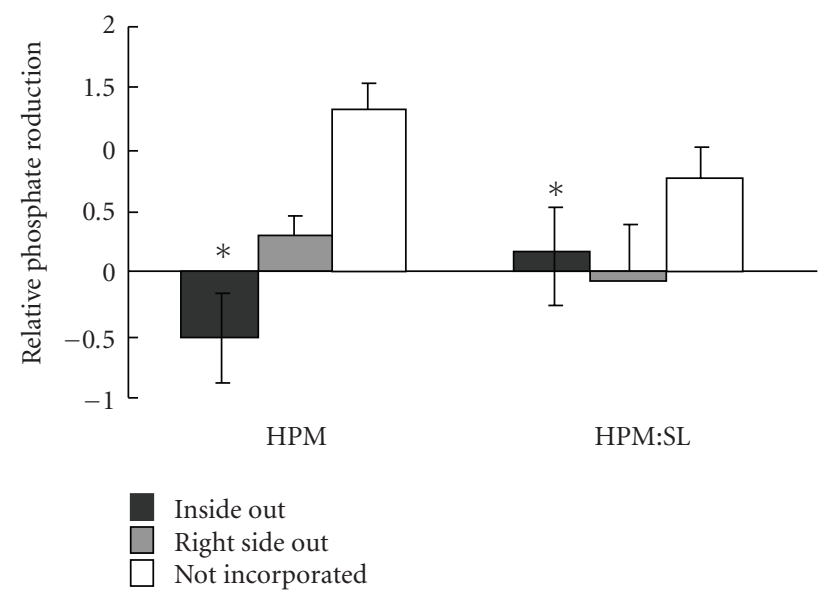

Figure 6: Orientation of $\mathrm{Na}^{+} \mathrm{K}^{+}$-ATPase in HPM alone and in HPM: SL proteoliposomes measured by the sidedness assay. Proteoliposomes were created by nitrogen filtration using HPM or HPM: SL lipids ( $1: 1$; wt : wt), incubated \pm ouabain \pm detergent and then function $\left(\mathrm{PO}_{4}\right.$ production from ATP) was measured and used to calculate sidedness [33] to determine the relative amount of $\mathrm{Na}^{+} \mathrm{K}^{+}$-ATPase that was facing inside out, right side out, or was not incorporated. Differences between HPM proteoliposomes and HPM: SL proteoliposomes are indicated by $*$.

4.3. Proteoliposome Function. Functionality of ATPase in liposomes was assessed by measuring the enzymatic ability to cleave phosphate from ATP. Proteoliposomes containing $\mathrm{Na}^{+}$ $\mathrm{K}^{+}$-ATPase produced significantly more $\mathrm{PO}_{4}$ than BSA or $\alpha$-amylase proteoliposomes, or liposomes alone, indicating that the incorporated $\mathrm{Na}^{+} \mathrm{K}^{+}$-ATPase enzyme is indeed functional under the optimal assay conditions of $10: 1$ lipid:protein incubated for 60 minutes incubation time, which is in the range used by others [23]. 
4.4. Orientation of $\mathrm{Na}^{+} \mathrm{K}^{+}$-ATPase in HPM Liposomes. Having demonstrated a reliable method to produce proteoliposomes with functional incorporated ATPase in the bilayer, it was important to know the orientation of the enzyme. Certainly the lipids in sperm head plasma membranes are not randomly distributed [39-41]. Furthermore, since HPM lipids from boar sperm form distinct domains of differing fluidities, which change over time, or with cryopreservation and/or with the medium in which sperm are preserved [42], the HPM lipids in the liposomes here were expected to similarly organize in a nonrandom manner. If the $\mathrm{Na}^{+} \mathrm{K}^{+}$-ATPase preferentially interacted with certain lipids, its orientation should be nonrandom, which was exactly what the sidedness assay indicated. All the enzyme that was incorporated, was incorporated in a right-side-out orientation ( $\beta$ subunit facing outwards). Others have found that the sidedness of $\mathrm{Na}^{+} \mathrm{K}^{+}$-ATPase in artificial membrane differs depending on the source of protein, the method of reconstitution, and especially on the lipid composition of the vesicles [23]. Vesicles of PC made by detergent dialysis caused $50 \%$ of ATPase to orient inside out [43], while in liposomes made of PE, PC, PI, and cholesterol by Bio Bead detergent removal, the ratio for $\mathrm{Na}^{+} \mathrm{K}^{+}$-ATPase right side out: inside out: not oriented was $65: 15: 20$ [44]. The liposomes here made by nitrogen filtration with native sperm HPM lipids allowed effective incorporation of functional $\mathrm{Na}^{+} \mathrm{K}^{+}$-ATPase, albeit at a low level.

4.5. Effect of Lipid Composition on Orientation of $\mathrm{Na}^{+} \mathrm{K}^{+}$ATPase. Altering the lipid composition of the vesicles did not affect the amount of protein that was not incorporated but did affect the orientation of $\mathrm{Na}^{+} \mathrm{K}^{+}$-ATPase in the membrane. When the bilayers contained endogenous native lipids, all the ATPase was oriented with its $\beta$ subunit in the outer leaflet, but replacing the HPM with $50 \%$ selected mixed lipids significantly increased the amount of $\mathrm{Na}^{+} \mathrm{K}^{+}$-ATPase oriented with its $\beta$ subunit in the inner leaflet.

$\mathrm{Na}^{+} \mathrm{K}^{+}$-ATPase orientation in reconstituted vesicles is affected by lipid composition, more specifically by the acyl chain lengths of phospholipids [45], the degree of saturation of the phospholipids [46], and the amount of cholesterol present $[47,48]$. Acyl chain lengths of phospholipids are important for determining the thickness of membrane bilayers. Bilayers that are too thick or too thin to accommodate the hydrophobic region of $\mathrm{Na}^{+} \mathrm{K}^{+}$-ATPase may result in improper folding, altered function, and differing levels of inclusion of ATPase [49]. Increasing the acyl chain length of monounsaturated PC results in an increase in the amount of $\mathrm{Na}^{+} \mathrm{K}^{+}$-ATPase that is not incorporated into liposomes, and the optimal amount of protein incorporated into liposomes occurs at 14- and 20-carbon chain length for unsaturated and saturated PC, respectively [50]. Cholesterol inclusion works to increase the thickness and order of plasma membranes [51] and it has been suggested that some membrane domains are formed only in the presence of certain concentrations of cholesterol [52]. Lipid rafts are enriched in cholesterol, sphingomyelin, lipids with saturated long chain acyl chains, [1] and in sperm, the plasma membrane which lays over the acrosome displays rafts enriched in gangliosides and cholesterol [53, 54]. Cholesterol content of membranes both above and below native membrane content $(16 \mathrm{moL} \%$ of total lipids) decreases $\mathrm{Na}^{+} \mathrm{K}^{+}$-ATPase activity in PC liposomes using pig kidney ATPase [47]. While the addition of $40 \mathrm{moL} \%$ cholesterol into PC liposomes had no effect on the amount of $\mathrm{Na}^{+} \mathrm{K}^{+}$-ATPase that was not incorporated into liposomes, it doubled the amount of enzyme that was inside out (right-side-out enzyme was not measured; [50]).

The extracted HPM lipids were measured and consisted of $45.2 \%$ PC, 9.7\% PE, 5.7\% Sph, 5.4\% PI, 4.2\% PS, and $29.8 \%$ cholesterol, with $29.3 \%$ of the total phospholipids being saturated. Most saturated phospholipids were 16 carbons long, while the majority of the unsaturated phospholipids had 22 carbon acyl chains. Therefore liposomes made with 50\% HPM:50\% selected lipids would have increased quantities of Sph $(16: 0$ and $18: 0)$ and PE $(18: 0)$, along with moderate increases in other phospholipids. The amount of overall cholesterol would be decreased by $50 \%$. Although reducing the cholesterol did not affect the amount of ATPase incorporated into the liposomes, either here or for Cornelius [50], the lower cholesterol content could have caused the altered orientation, since removal of cholesterol from sperm membranes alters raft structure, changing the size, distribution, and content of glycoproteins [54-56]. It would be interesting to test ATPase orientation in liposomes with systematically altered cholesterol content.

Lipid rafts have been variously suggested to break down [57] or become enriched $[3,54]$ during sperm capacitation. Regardless of how rafts change, it is clear that the lipid rafts in sperm membranes change during capacitation. Seminolipid, a sperm-specific glycolipid concentrated in the outer leaflet of the plasma membrane on the apical ridge of the sperm head $[56,58]$, may have the ability to stabilize the plasma membrane, preventing the acrosome reaction $[56,59]$. Depleting cholesterol from the plasma membrane during capacitation facilitates the removal of seminolipid [60]. Consistent with activation of $\mathrm{Na}^{+} \mathrm{K}^{+}$-ATPase by raftmediated relocation in other cells $[19,20]$, ATPase in sperm may be relocated in the plasma membrane by the efflux of cholesterol during capacitation so that it is accessible to bind ouabain and initiate signalling cascade. Cholesterol efflux from sperm membranes during capacitation occurs more readily in nonraft or fluid fractions of the membrane [54]. Certainly the current results demonstrate that $\mathrm{Na}^{+}$ $\mathrm{K}^{+}$-ATPase is sensitive to its lipid environment, and that lipid environment alters its orientation, and therefore its accessibility to external stimuli such as ouabain.

\section{Conclusions}

Functional $\mathrm{Na}^{+} \mathrm{K}^{+}$-ATPase can be incorporated into proteoliposomes. High pressure nitrogen filtration applied to native lipids extracted from sperm membranes reliably creates consistently sized liposomes and proteoliposomes. FRET elegantly proves that the proteoliposomes have actually incorporated the amylase or ATPase proteins into the lipid bilayer. Incorporated ATPase is functional and, in a bilayer 
of native lipids, is oriented exclusively in a right side-out orientation. Alteration of the lipid composition changes the orientation of $\mathrm{Na}^{+} \mathrm{K}^{+}$-ATPase in the lipid bilayer, confirming that specific lipids effectively influence integral membrane proteins. These results support recent results suggesting that inclusion of raft-associated lipids and proteins may increase the quantity and stabilize the orientation of $\mathrm{Na}^{+} \mathrm{K}^{+}$-ATPase in model, or cellular, membranes.

\section{References}

[1] H. Post, A. Schwarz, T. Brandenburger, G. Aumüller, and B. Wilhelm, "Arrangement of PMCA4 in bovine sperm membrane fractions," International Journal of Andrology, vol. 33, no. 6, pp. 775-783, 2010.

[2] M. Edidin, "Lipids on the frontier: a century of cell-membrane bilayers," Nature Reviews Molecular Cell Biology, vol. 4, no. 5, pp. 414-418, 2003.

[3] M. B. Khalil, K. Chakrabandhu, H. Xu et al., "Sperm capacitation induces an increase in lipid rafts having zona pellucida binding ability and containing sulfogalactosylglycerolipid," Developmental Biology, vol. 290, no. 1, pp. 220-235, 2006.

[4] R. Yanagimachi, "Mammalian fertilization," in The Physiology of Reproduction, E. Knobil and J. Neill, Eds., vol. 1, pp. 189317, Raven Press, New York, NY, USA, 1994.

[5] B. M. Gadella, P. S. Tsai, A. Boerke, and I. A. Brewis, "Sperm head membrane reorganisation during capacitation," International Journal of Developmental Biology, vol. 52, no. 5-6, pp. 473-480, 2008.

[6] B. Nixon and R. J. Aitken, "The biological significance of detergent-resistant membranes in spermatozoa," Journal of Reproductive Immunology, vol. 83, no. 1-2, pp. 8-13, 2009.

[7] J. C. Thundathil, M. Anzar, and M. M. Buhr, " $\mathrm{Na}^{+} / \mathrm{K}^{+}$ATPase as a signaling molecule during bovine sperm capacitation," Biology of Reproduction, vol. 75, no. 3, pp. 308-317, 2006.

[8] Y. Zhao and M. M. Buhr, "Localization of various ATPases in fresh and cryopreserved bovine spermatozoa," Animal Reproduction Science, vol. 44, no. 3, pp. 139-148, 1996.

[9] M. M. Buhr, E. Curtis, and N. Kakuda, "Effect of boar sperm cryopreservation on the composition and behaviour of head membrane lipids," Cryobiology, vol. 31, pp. 224-238, 1994.

[10] A. L. Woo, P. F. James, and J. B. Lingrel, "Characterization of the fourth $\alpha$ isoform of the $\mathrm{Na}^{+}, \mathrm{K}^{+}$-ATPase," Journal of Membrane Biology, vol. 169, no. 1, pp. 39-44, 1999.

[11] O. D. Lopina, "Interaction of $\mathrm{Na}^{+}, \mathrm{K}^{+}$-ATPase catalytic subunit with cellular proteins and other endogenous regulators," Biochemistry, vol. 66, no. 10, pp. 1122-1131, 2001.

[12] J. B. Lingrel and T. Kuntzweiler, " $\mathrm{Na}^{+}, \mathrm{K}^{+}$-ATPase," Journal of Biological Chemistry, vol. 269, no. 31, pp. 19659-19662, 1994.

[13] M. Haas, A. Askari, and Z. Xie, "Involvement of Src and epidermal growth factor receptor in the signal-transducing function of $\mathrm{Na}^{+} / \mathrm{K}^{+}$-ATPase," Journal of Biological Chemistry, vol. 275, no. 36, pp. 27832-27837, 2000.

[14] G. P. Eckert, U. Igbavboa, W. E. Müller, and W. G. Wood, "Lipid rafts of purified mouse brain synaptosomes prepared with or without detergent reveal different lipid and protein domains," Brain Research, vol. 962, no. 1-2, pp. 144-150, 2003.

[15] P. Welker, B. Geist, J. H. Frühauf et al., "Role of lipid rafts in membrane delivery of renal epithelial $\mathrm{Na}^{+}-\mathrm{K}^{+}$-ATPase, thick ascending limb," American Journal of Physiology, vol. 292, no. 3, pp. R1328-R1337, 2007.
[16] T. Fujii, Y. Takahashi, Y. Itomi et al., "K-Cl cotransporter-3a up-regulates $\mathrm{Na}^{+}, \mathrm{K}^{+}$-ATPase in lipid rafts of gastric luminal parietal cells," Journal of Biological Chemistry, vol. 283, no. 11, pp. 6869-6877, 2008.

[17] A. Mazzone, P. Tietz, J. Jefferson, R. Pagano, and N. F. LaRusso, "Isolation and characterization of lipid microdomains from apical and basolateral plasma membranes of rat hepatocytes," Hepatology, vol. 43, no. 2, pp. 287-296, 2006.

[18] L. Liu, K. Mohammadi, B. Aynafshar et al., "Role of caveolae in signal-transducing function of cardiac $\mathrm{Na}^{+} / \mathrm{K}^{+}$-ATPase," American Journal of Physiology, vol. 284, no. 6, pp. C1550C1560, 2003.

[19] L. Lavoie, D. Roy, T. Ramlal et al., "Insulin-induced translocation of $\mathrm{Na}^{+}-\mathrm{K}^{+}$-ATPase subunits to the plasma membrane is muscle fiber type specific," American Journal of Physiology, vol. 270, no. 5, pp. C1421-C1429, 1996.

[20] D. Lingwood, G. Harauz, and J. S. Ballantyne, "Regulation of fish gill $\mathrm{Na}^{+}-\mathrm{K}^{+}$-ATPase by selective sulfatide-enriched raft partitioning during seawater adaptation," Journal of Biological Chemistry, vol. 280, no. 44, pp. 36545-36550, 2005.

[21] J. L. Rigaud, D. Levy, G. Mosser, and O. Lambert, "Detergent removal by non-polar polystyrene beads: applications to membrane protein reconstitution and two-dimensional crystallization," European Biophysics Journal, vol. 27, no. 4, pp. 305-319, 1998.

[22] B. J. Battersby, G. A. Lawrie, and G. T. Barnes, "Vesicle formation in aqueous dimyristoyl phosphatidylcholine suspensions: a cryo-electron microscopy study," Colloids and Surfaces B, vol. 13, no. 4, pp. 179-185, 1999.

[23] F. Cornelius, "Functional reconstitution of the sodium pump. Kinetics of exchange reactions performed by reconstituted $\mathrm{Na}^{+} / \mathrm{K}^{+}$-ATPase," Biochimica et Biophysica Acta, vol. 1071, no. 1, pp. 19-66, 1991.

[24] C. D’Antuono, M. Del Carmen Fernández-Tomé, N. SterinSpeziale, and D. L. Bernik, "Lipid-protein interactions in rat renal subcellular membranes: a biophysical and biochemical study," Archives of Biochemistry and Biophysics, vol. 382, no. 1, pp. 39-47, 2000.

[25] A. Chávez, M. Pujol, M. A. Alsina, and Y. Cajal, "Membrane fusion induced by a lipopeptidic epitope from VP3 capside protein of hepatitis A virus," Luminescence, vol. 16, no. 2, pp. 135-143, 2001.

[26] E. Haque, T. J. McIntosh, and B. R. Lentz, "Influence of lipid composition on physical properties and PEG-mediated fusion of curved and uncurved model membrane vesicles: "Nature's own" fusogenic lipid bilayer," Biochemistry, vol. 40, no. 14, pp. 4340-4348, 2001.

[27] D. R. Yingst, S. Y. Yang, and R. Schiebinger, "Purification of active $\mathrm{Na}^{+}-\mathrm{K}^{+}$-ATPase using a new ouabain-affinity column," American Journal of Physiology, vol. 275, no. 4, pp. C1167C1177, 1998.

[28] D. G. Dalgleish and F. R. Hallett, "Dynamic light scattering: applications to food systems," Food Research International, vol. 28, no. 3, pp. 181-193, 1995.

[29] P. Allan-Wojtas and M. Kalab, "Milk gel structure. XIV. Fixation of fat globules in whole milk yoghurt for electron microscopy," Milk Science International, vol. 39, pp. 323-327, 1984.

[30] K. Viljanen, R. Kivikari, and M. Heinonen, "Protein-lipid interactions during liposome oxidation with added anthocyanin and other phenolic compounds," Journal of Agricultural and Food Chemistry, vol. 52, no. 5, pp. 1104-1111, 2004. 
[31] S. Chifflet, A. Torriglia, R. Chiesa, and S. Tolosa, "A method for the determination of inorganic phosphate in the presence of labile organic phosphate and high concentrations of protein: application to lens ATPase," Analytical Biochemistry, vol. 168, no. 1, pp. 1-4, 1988.

[32] C. A. Doige, X. Yu, and F. J. Sharom, "ATPase activity of partially purified P-glycoprotein from multidrug-resistant Chinese hamster ovary cells," Biochimica et Biophysica Acta, vol. 1109, no. 2, pp. 149-160, 1992.

[33] F. Cornelius, "Incorporation of CE-solubilized $\mathrm{Na}^{+}, \mathrm{K}^{+}-$ ATPase into liposomes: determination of sidedness and orientation," Methods in Enzymology, vol. 156, pp. 156-167, 1988.

[34] L. He, J. L. Bailey, and M. M. Buhr, "Incorporating lipids into boar sperm decreases chilling sensitivity but not capacitation potential," Biology of Reproduction, vol. 64, no. 1, pp. 69-79, 2001.

[35] K. Ohdan, T. Kuriki, H. Kaneko et al., "Characteristics of two forms of $\alpha$-amylases and structural implication," Applied and Environmental Microbiology, vol. 65, no. 10, pp. 4652-4658, 1999.

[36] D. Tang, D. Borchman, and M. C. Yappert, "Alphacrystallin/lens lipid interactions using resonance energy transfer," Ophthalmic Research, vol. 31, no. 6, pp. 452-462, 1999.

[37] J. L. Rigaud, B. Pitard, and D. Levy, "Reconstitution of membrane proteins into liposomes: application to energytransducing membrane proteins," Biochimica et Biophysica Acta, vol. 1231, no. 3, pp. 223-246, 1995.

[38] J. J. Lacapère, D. L. Stokes, A. Olofsson, and J. L. Rigaud, "Two-dimensional crystallization of Ca-ATPase by detergent removal,” Biophysical Journal, vol. 75, no. 3, pp. 1319-1329, 1998.

[39] J. E. Parks and D. V. Lynch, "Lipid composition and thermotropic phase behavior of boar, bull, stallion, and rooster sperm membranes," Cryobiology, vol. 29, no. 2, pp. 255-266, 1992.

[40] D. E. Wolf, "Lipid domains in sperm plasma membranes," Molecular Membrane Biology, vol. 12, no. 1, pp. 101-104, 1995.

[41] C. A. Wolfe, P. S. James, A. R. Mackie, S. Ladha, and R. Jones, "Regionalized lipid diffusion in the plasma membrane of mammalian spermatozoa," Biology of Reproduction, vol. 59, no. 6, pp. 1506-1514, 1998.

[42] M. M. Buhr and M. J. Pettitt, "Frozen-thawed boar sperm: isolation of membranes and fluidity measurement," Reproduction in Domestic Animals. Supplement, vol. 31, no. 1, pp. 147-152, 1996.

[43] B. M. Anner and B. Volet, "Uptake of reconstituted $\mathrm{Na}^{+}, \mathrm{K}^{+}$ATPase vesicles by isolated lymphocytes measured by FACS, confocal microscopy and spectrofluorometry," Cell Biochemistry and Biophysics, vol. 30, no. 3, pp. 437-454, 1999.

[44] F. Cornelius and J. C. Skou, "Reconstitution of $\left(\mathrm{Na}^{+}+\mathrm{K}^{+}\right)$ATPase into phospholipid vesicles with full recovery of its specific activity," Biochimica et Biophysica Acta, vol. 772, no. 3, pp. 357-373, 1984.

[45] A. Johannsson, G. A. Smith, and J. C. Metcalfe, "The effect of bilayer thickness on the activity of $\left(\mathrm{Na}^{+}+\mathrm{K}^{+}\right)$-ATPase," Biochimica et Biophysica Acta, vol. 641, no. 2, pp. 416-421, 1981.

[46] M. Y. Abeywardena, T. M. Allen, and J. S. Charnock, "Lipidprotein interactions of reconstituted membrane-associated adenosinetriphosphatases. Use of a gel-filtration procedure to examine phospholipid-activity relationships," Biochimica et Biophysica Acta, vol. 729, no. 1, pp. 62-74, 1983.
[47] P. L. Yeagle, J. Young, and D. Rice, "Effects of cholesterol on $\left(\mathrm{Na}^{+}, \mathrm{K}^{+}\right)$-ATPase ATP hydrolyzing activity in bovine kidney," Biochemistry, vol. 27, no. 17, pp. 6449-6452, 1988.

[48] F. Cornelius, "Cholesterol modulation of molecular activity of reconstituted shark $\mathrm{Na}^{+}, \mathrm{K}^{+}$-ATPase," Biochimica et Biophysica Acta, vol. 1235, no. 2, pp. 205-212, 1995.

[49] O. G. Mouritsen and M. Bloom, "Mattress model of lipidprotein interactions in membranes," Biophysical Journal, vol. 46, no. 2, pp. 141-163, 1984.

[50] F. Cornelius, "Modulation of $\mathrm{Na}^{+}, \mathrm{K}^{+}$-ATPase and Na-ATPase activity by phospholipids and cholesterol. I. Steady-state kinetics," Biochemistry, vol. 40, no. 30, pp. 8842-8851, 2001.

[51] J. Hjort Ipsen, G. Karlström, O. G. Mourtisen, H. Wennerström, and M. J. Zuckermann, "Phase equilibria in the phosphatidylcholine-cholesterol system," Biochimica et Biophysica Acta, vol. 905, no. 1, pp. 162-172, 1987.

[52] C. P. Sotomayor, L. F. Aguilar, F. J. Cuevas, M. K. Helms, and D. M. Jameson, "Modulation of pig kidney $\mathrm{Na}^{+} / \mathrm{K}^{+}$-ATPase activity by cholesterol: role of hydration," Biochemistry, vol. 39, no. 35, pp. 10928-10935, 2000.

[53] A. Asano, V. Selvaraj, D. E. Buttke et al., "Biochemical characterization of membrane fractions in murine sperm: identification of three distinct sub-types of membrane rafts," Journal of Cellular Physiology, vol. 218, no. 3, pp. 537-548, 2009.

[54] A. Boerke, P. S. Tsai, N. Garcia-Gil, I. A. Brewis, and B. M. Gadella, "Capacitation-dependent reorganization of microdomains in the apical sperm head plasma membrane: functional relationship with zona binding and the zonainduced acrosome reaction," Theriogenology, vol. 70, no. 8, pp. 1188-1196, 2008.

[55] P. S. Kabouridis, J. Janzen, A. L. Magee, and S. C. Ley, "Cholesterol depletion disrupts lipid rafts and modulates the activity of multiple signaling pathways in T lymphocytes," European Journal of Immunology, vol. 30, no. 3, pp. 954-963, 2000.

[56] B. M. Gadella, P. S. Tsai, A. Boerke, and I. A. Brewis, "Sperm head membrane reorganisation during capacitation," International Journal of Developmental Biology, vol. 52, no. 5-6, pp. 473-480, 2008.

[57] S. B. Sleight, P. V. Miranda, N. W. Plaskett et al., "Isolation and proteomic analysis of mouse sperm detergent-resistant membrane fractions: evidence for dissociation of lipid rafts during capacitation," Biology of Reproduction, vol. 73, no. 4, pp. 721-729, 2005.

[58] B. M. Gadella, M. Lopes-Cardozo, L. M. G. Van Golde, B. Colenbrander, and T. W. J. Gadella, "Glycolipid migration from the apical to the equatorial subdomains of the sperm head plasma membrane precedes the acrosome reaction. Evidence for a primary capacitation event in boar spermatozoa," Journal of Cell Science, vol. 108, no. 3, pp. 935-946, 1995.

[59] B. M. Gadella and R. A. Van Gestel, "Bicarbonate and its role in mammalian sperm function," Animal Reproduction Science, vol. 82-83, pp. 307-319, 2004.

[60] B. M. Gadella, R. Rathi, J. F. H. M. Brouwers, T. A. E. Stout, and B. Colenbrander, "Capacitation and the acrosome reaction in equine sperm," Animal Reproduction Science, vol. 68, no. 3-4, pp. 249-265, 2001. 

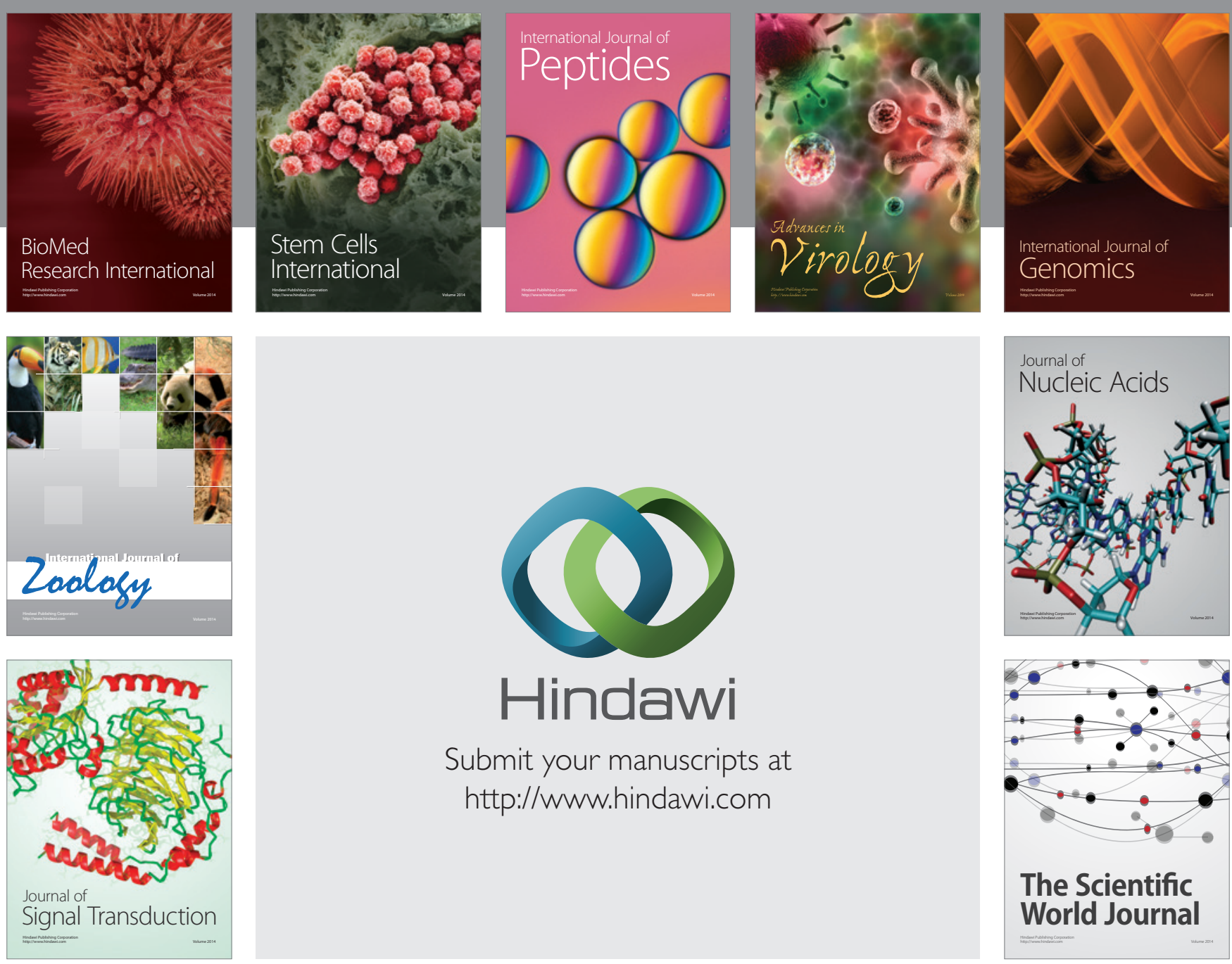

Submit your manuscripts at

http://www.hindawi.com
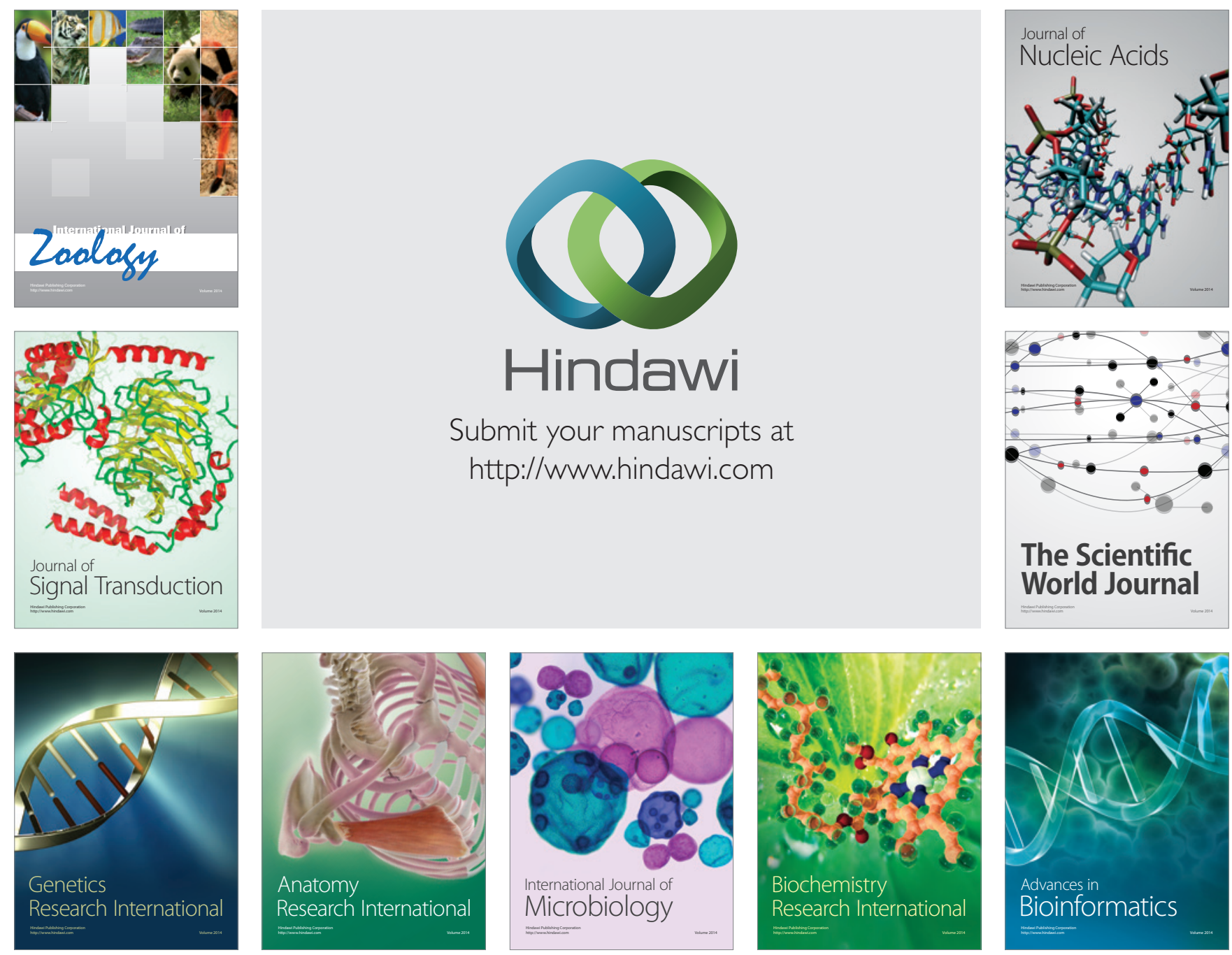

The Scientific World Journal
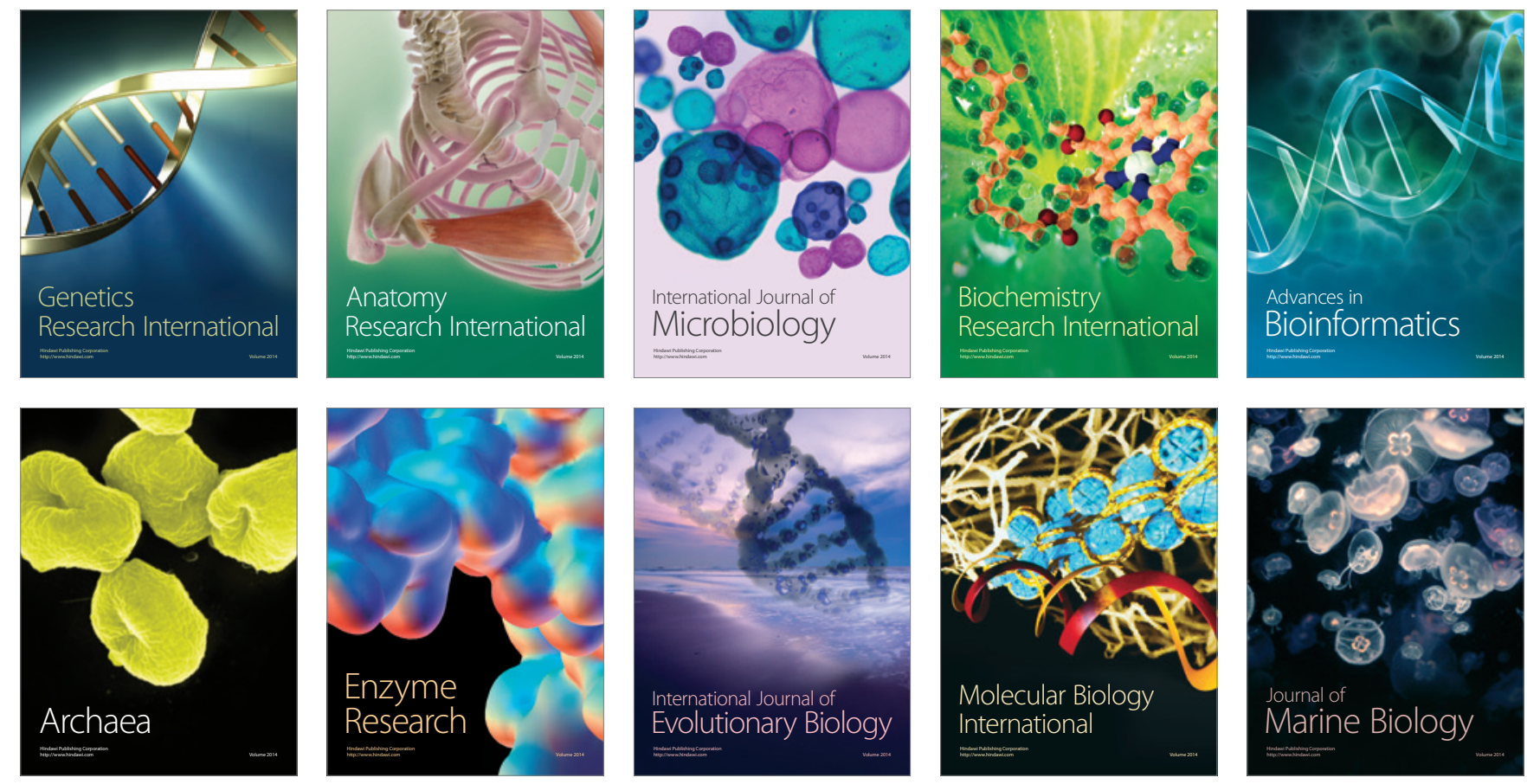